\title{
Variation of the Side Chain Branch Position Leads to Vastly Improved Molecular Weight and OPV Performance in 4,8-dialkoxybenzo[1,2-b:4,5-b'] dithiophene/ 2,1,3-benzothiadiazole Copolymers
}

\author{
Robert C. Coffin, ${ }^{1}$ Christopher M. MacNeill, ${ }^{2}$ Eric D. Peterson, ${ }^{1}$ \\ Jeremy W. Ward, ${ }^{1}$ Jack W. Owen, ${ }^{1}$ Claire A. McLellan, ${ }^{1}$ Gregory M. Smith, ${ }^{1}$ \\ Ronald E. Noftle, ${ }^{2}$ Oana D. Jurchescu, ${ }^{1}$ and David L. Carroll ${ }^{1}$ \\ ${ }^{1}$ The Department of Physics and the Center for Nanotechnology and Molecular Materials, Wake Forest University, Winston-Salem, \\ NC 27109, USA \\ ${ }^{2}$ The Department of Chemistry, Wake Forest University, Winston-Salem, NC 27109, USA \\ Correspondence should be addressed to Robert C. Coffin, coffinrc@wfu.edu
}

Received 2 February 2011; Accepted 13 April 2011

Academic Editor: Román López-Sandoval

Copyright () 2011 Robert C. Coffin et al. This is an open access article distributed under the Creative Commons Attribution License, which permits unrestricted use, distribution, and reproduction in any medium, provided the original work is properly cited.

Through manipulation of the solubilizing side chains, we were able to dramatically improve the molecular weight $\left(M_{w}\right)$ of 4,8-dialkoxybenzo[1,2- $\left.b: 4,5-b^{\prime}\right]$ dithiophene (BDT)/2,1,3-benzothiadiazole (BT) copolymers. When dodecyl side chains (P1) are employed at the 4- and 8-positions of the BDT unit, we obtain a chloroform-soluble copolymer fraction with $M_{w}$ of $6.3 \mathrm{~kg} / \mathrm{mol}$. Surprisingly, by moving to the commonly employed 2-ethylhexyl branch (P2), $M_{w}$ decreases to $3.4 \mathrm{~kg} / \mathrm{mol}$. This is despite numerous reports that this side chain increases solubility and $M_{w}$. By moving the ethyl branch in one position relative to the polymer backbone (1-ethylhexyl, P3), $M_{w}$ is dramatically increased to $68.8 \mathrm{~kg} / \mathrm{mol}$. As a result of this $M_{w}$ increase, the shape of the absorption profile is dramatically altered, with $\lambda_{\max }=637 \mathrm{~nm}$ compared with $598 \mathrm{~nm}$ for P1 and $579 \mathrm{~nm}$ for P2. The hole mobility as determined by thin film transistor (TFT) measurements is improved from $\sim 1 \times 10^{-6} \mathrm{~cm}^{2} / \mathrm{Vs}$ for $\mathbf{P} \mathbf{1}$ and $\mathbf{P} 2$ to $7 \times 10^{-4} \mathrm{~cm} / \mathrm{Vs}$ for P3, while solar cell power conversion efficiency in increased to $2.91 \%$ for $\mathbf{P 3}$ relative to $0.31 \%$ and $0.19 \%$ for P1 and $\mathbf{P 2}$, respectively.

\section{Introduction}

Over the past few years considerable attention has been drawn to the field of organic photovoltaics (OPVs) [1-3]. These devices are lightweight and can be made on flexible substrates via low cost roll-to-roll processing offering a more affordable alternative to traditional PVs based on inorganic semiconductors [4-6]. However, a major stumbling block has been that OPVs are typically far less efficient than their inorganic counterparts. OPV power conversion efficiencies (PCEs) need to be dramatically improved in order to compete with inorganics and improved further still to achieve grid parity. Recently, researchers have made great strides in improving OPV PCEs from $<4 \%$ in 2001 to the current record of $8.3 \%$ [7].

These devices employ a bulk heterojunction (BHJ) architecture consisting of an active (absorbing) layer, comprised of a phase-separated network of a polymer donor (p-type) phase and a fullerene acceptor (n-type) phase sandwiched between an anode and cathode. Ideally, the domain sizes within the active layer are less than $10 \mathrm{~nm}$, ensuring that excitons generated within the bulk of a phase are able to diffuse to the donor-acceptor interface, where charge separation occurs. It is also necessary that the network is bicontinuous to ensure that the separated charges have unobstructed paths to their respective electrodes. Improving 
the active layer, both its components (donor and acceptor) and its morphology are the subject of the majority of OPV research and accounts for the recent upsurge in PCEs. Contributing to these improvements are (1) new processing methods that allow for more ideal phase separation and ordering within the absorbing layer [8-14], (2) new fullerene acceptor materials with elevated lowest unoccupied molecular orbitals (LUMOs) that allow for improved open circuit voltages $\left(V_{\text {oc }}\right)$ and in-turn PCEs $[15,16]$ and (3) new polymer materials with highest occupied molecular orbital (HOMO) and LUMO energy levels designed specifically for OPV applications [17].

Hundreds of low bandgap polymers have now been reported for BHJ solar cells [17]. However, despite many new materials having attractive HOMO and LUMO levels for OPV applications, only a small fraction has been fabricated into efficient (PCE $>5 \%$ ) organic solar cells. Frequently, this is a result of low molecular weight and poor solubility. It has been shown that higher molecular weights are generally required for good charge transport and OPV performance, while good solubility is required for the fabrication of uniform thin films and general ease of film deposition. Molecular weight and solubility often go hand-in-hand, since molecular weight growth can be terminated by precipitation of a poorly soluble polymer chain. Fortunately, $M_{n}$ and solubility can often be simultaneously improved by altering the side chains on the polymer.

With this in mind, we were interested in improving the molecular weight of a copolymer $(\mathrm{H} 7)$ of 4,8 didodecoxybenzo[1,2-b:4,5-b'] dithiophene $\left(\mathrm{C}_{12}-\mathrm{BDT}\right)$ and 2,1,3-benzothiadiazole (BT) reported by Hou et al. [18]. When employed in a bulk heterojunction solar cell, this polymer exhibited a PCE of $0.9 \%$, which seemed particularly low considering that both BDT and BT have been employed in copolymers that have been used to fabricate highly efficient OPVs [11, 19-26]. In more recent reports of BDT copolymers, it has been suggested that linear alkoxy chains at the 4 and 8 positions of BDT result in poorly processable low molecular weight $\left(M_{w}\right)$ materials $[20,26]$. We anticipated that by altering the side chains from linear (dodecoxy) to branched, we could enhance $M_{w}$ and solubility, and in turn improve upon the PCE of $\mathbf{H 7}$.

In this paper, we detail the syntheses, characterization, and photovoltaic properties of copolymers comprised of 4,8dialkoxybenzo[1,2-b:4,5- $\left.\mathrm{b}^{\prime}\right]$ dithiophene (BDT) and 2,1,3benzothiadiazole, where dodecoxy (P1, H7), 2-ethylhexyl (P2) and 1-ethylhexyl (P3) side chains are employed at the 4and 8-positions (see Scheme 1). This contribution focuses on how simple alteration of the solubilizing side chains can lead to significant increases in polymer molecular weight, charge transport, and photovoltaic performance.

\section{Experimental Section}

2.1. Materials. 3-Thiophenecarboxylic acid (1) was purchased from Matrix Scientific Co. Diethylamine, thionyl chloride, n-butyllithium (1.6 M in hexanes), trimeth- yltin chloride, CAUTION: trimethyltin chloride is a neurotoxin, and proper precaution should be taken when handling it, 2-ethylhexyl bromide, methanesulfonyl chloride and 3octanol were purchased from Aldrich Chemical Co. Bromine was purchased from Fisher Chemical Co. Palladium tetrakistriphenyl-phosphine was purchased from Acros Chemical Co. 1-bromododecane and tetrabutylammonium bromide were purchased from Eastman Chemical Co. All other reagents were purchased from common commercial sources and used without further purification unless otherwise noted. THF was dried over Na/benzophenone ketal. 4,7Dibromo-2,1,3-benzothiadiazole (11) was syn-the-sized according to literature procedure [27]. The nonstannylated 4,8-didodecyloxybenzo[1,2-b:4,5- $\left.\mathrm{b}^{\prime}\right]$ dithiophene (5) and 4,8-bis(2-ethylhexyloxy)benzo[1,2-b:4,5- $\left.\mathrm{b}^{\prime}\right]$ dithiophene (6) were synthesized according to the published procedures $[18,21]$.

2.2. Instrumentation. Flash chromatography was performed on a Biotage Isolera Flash Purification System using Biotage SNAP Flash Purification Cartridges as the stationary phase. Microwave-assisted polymerizations were carried out using a CEM Discover Microwave reactor. ${ }^{1} \mathrm{H}$ and ${ }^{13} \mathrm{C}$ NMR spectra were recorded on a Bruker Avance DPX-300 NMR spectrometer. ${ }^{119}$ Sn NMR spectra were recorded on a Bruker Avance DRX-500 instrument. UV-vis absorption spectra were recorded on an Agilent 8453 diode-array spectrophotometer operating over a range of $190-1100 \mathrm{~nm}$. GC-MS were recorded on an Agilent 6850 Series GC system coupled to an Agilent 5973 mass selective detector run in electron impact mode. Infrared spectra were recorded over the $450-4000 \mathrm{~cm}^{-1}$ region using on a Perkin Elmer Spectrum 100 spectrophotometer with an ATR sampling accessory equipped with a diamond anvil. Gel permeation chromatography $\left(135^{\circ} \mathrm{C}\right.$ in $1,2,4$-trichlorobenzene) was performed by American Polymer Standards (Ohio).

\subsection{Synthesis}

2.3.1. 3-Thiophenecarbonyl Chloride (2). 3-Thiophenecarboxylic acid $(20.0 \mathrm{~g}, 0.156 \mathrm{~mol})(\mathbf{1})$ was added to a round bottom flask equipped with a reflux condenser and stopper. Thionyl chloride $(100 \mathrm{~mL})$ was then added, and the mixture was allowed to reflux for 4 hours under a blanket of argon. The excess thionyl chloride was distilled over and the solution was dried on a vacuum line to yield colorless crystals $(22.7 \mathrm{~g}, 99 \%)$. Characterization was consistent with published data.

2.3.2. N,N-Diethylthiophene-3-carboxamide (3). 3-Thiophenecar-bonyl chloride $(13.2 \mathrm{~g}, 0.09 \mathrm{~mol})$ was dissolved in methylene chloride $(45 \mathrm{~mL})$ and added dropwise at $0^{\circ} \mathrm{C}$ to a solution of diethylamine $(25 \mathrm{~mL})$ in methylene chloride $(25 \mathrm{~mL})$. The solution was stirred at $0^{\circ} \mathrm{C}$ for 2 hours and then at RT overnight. Diethylamine $(10 \mathrm{~mL})$ was added and the mixture was stirred for another 2 hours. The diethylamine 


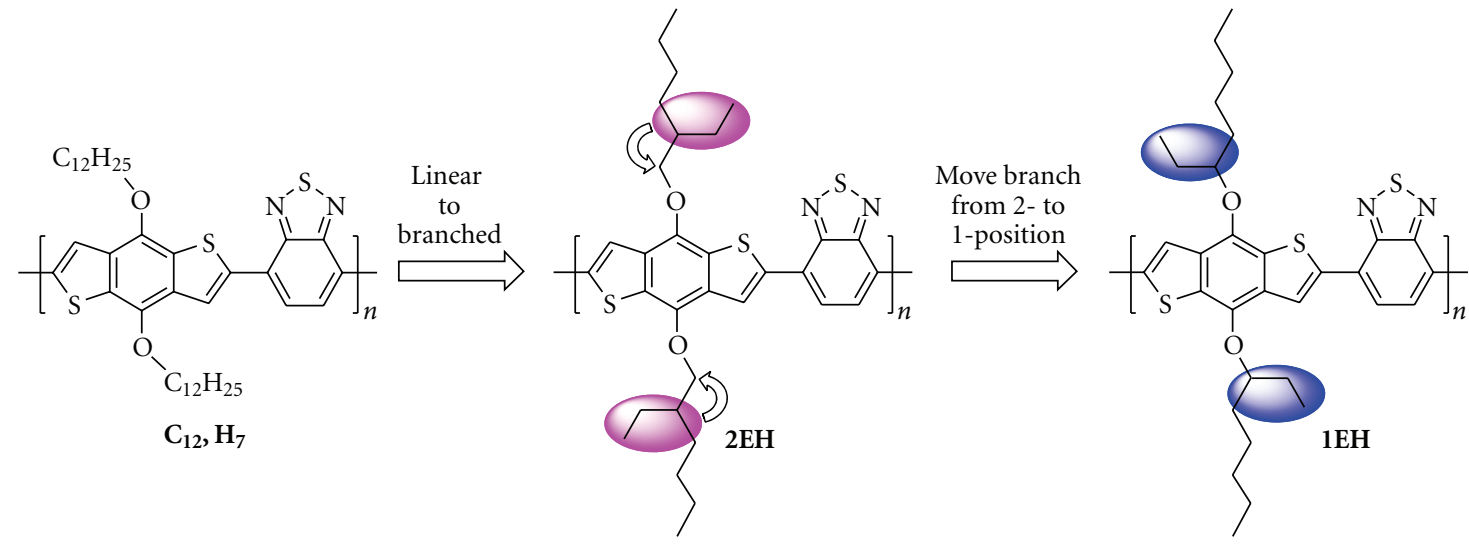

Scheme 1: Side chain variation in 4,8-dialkoxybenzo[1,2-b:4,5-b'] dithiophene (BDT) 2,1,3-benzothiadiazole copolymers.

hydrochloride precipitate was filtered off and the organic phase was extracted with water. The solution was dried over magnesium sulfate and evaporated to give a brown oil $(14.1 \mathrm{~g}, 85 \%)$. Characterization of the product was consistent with the published data. One pot procedure. 3Thiophenecarboxylic acid $(7.0 \mathrm{~g}, 0.055 \mathrm{~mol})$ and thionyl chloride $(5.0 \mathrm{~mL}, 0.068 \mathrm{~mol})$ were added to a round bottom flask containing methylene chloride $(200 \mathrm{~mL})$ and cooled to $0{ }^{\circ} \mathrm{C}$. Triethylamine $(15 \mathrm{~mL})$ was then added dropwise over 15 minutes resulting in the formation of a white precipitate. The mixture was allowed to warm to room temperature. After 30 minutes, diethylamine $(8 \mathrm{~mL})$ was added dropwise over 10 minutes. The mixture was stirred for an additional 30 minutes at room temperature. The methylene chloride was evaporated, then ether was added, and the triethylamine hydrochloride precipitate was filtered and washed with a small amount of ether. The ether was then evaporated to leave a brown oil $(8.6 \mathrm{~g}, 86 \%)$.

\subsubsection{4,8-Dihydrobenzo[1,2-b;4,5- $\left.b^{\prime}\right]$ dithiophene-4,8-dione} (4). Compound $2(14.1 \mathrm{~g}, 0.077 \mathrm{~mol})$ was added to a 2 -neck round bottom flask that was charged with dry THF $(50 \mathrm{~mL})$. $n$-Butyllithium ( $51 \mathrm{~mL}, 0.082 \mathrm{mmol}, 1.6 \mathrm{M}$ in hexanes) was added dropwise over 30 minutes at $0^{\circ} \mathrm{C}$. The mixture was allowed to stir at $0^{\circ} \mathrm{C}$ for 30 minutes and then at RT for 2 hours. The mixture was poured over ice and allowed to sit for 4 hours. The precipitate was filtered, washed with water and methanol, and the olive green product was allowed to dry in air overnight. Typical yields range from 75\%-92\%. Characterization was consistent with the published data.

\subsubsection{4,8-Bis(1-ethylhexyloxy)benzo[1,2-b:4,5- $\left.b^{\prime}\right]$ dithiophene} (7). Compound $3(4.0 \mathrm{~g}, 18.1 \mathrm{mmol})$ was added to a flask containing $\mathrm{Zn}$ dust $(2.6 \mathrm{~g}, 39.8 \mathrm{mmol})$ and $\mathrm{NaOH}$ $(85.0 \mathrm{~mL}, 25 \%)$ solution. The green mixture was allowed to reflux for 1 hour. The color changed to orange and 3octylmethanesulfonate $(7.3 \mathrm{~g}, 35 \mathrm{mmol})$, and tetrabutylammonium bromide $(600 \mathrm{mg}, \sim 10 \mathrm{~mol} \%)$ were added. After 2 hours, additional portions of 3-octylmesylate $(1.34 \mathrm{~g}$, $6.4 \mathrm{mmol})$ and $\mathrm{Zn}$ dust $(1.2 \mathrm{~g}, 18.3 \mathrm{mmol})$ were added, and the mixture was refluxed overnight. After cooling, the mixture was quenched with $\mathrm{H}_{2} \mathrm{O}$ and separated with ether. The organic phase was dried over $\mathrm{MgSO}_{4}$ and evaporated to yield an orange oil $(4.40 \mathrm{~g}, 54 \%) .{ }^{1} \mathrm{H}-\mathrm{NMR}\left(\mathrm{CDCl}_{3}\right), \delta$ (ppm): $7.47(\mathrm{~d}, 2 \mathrm{H}) ; 7.33(\mathrm{~d}, 2 \mathrm{H}) ; 4.52(\mathrm{~m}, 2 \mathrm{H}) ; 1.73(\mathrm{~m}$, $8 \mathrm{H}) ; 1.51(\mathrm{~m}, 4 \mathrm{H}) ; 1.30(\mathrm{~m}, 8 \mathrm{H}) 1.03(\mathrm{~m}, 6 \mathrm{H}) ; 0.89(\mathrm{~m}$, $6 \mathrm{H}) .{ }^{13} \mathrm{C}-\mathrm{NMR}\left(\mathrm{CDCl}_{3}\right), \delta(\mathrm{ppm}): 143.1,132.4,130.5,125.5$, $120.7,83.7,33.7,32.1,26.9,25.1,22.6,14.0,9.6$. MS (EI): calc'd 446.23, found $(\mathrm{M}+1)^{+}, 447.3$.

2.3.5. General Procedure for Stannylation of Compounds (5), (6), and (7). Compounds 5-7 in dry THF (20 equiv. by wt.) were cooled to $-78^{\circ} \mathrm{C}$ in an acetone/dry ice bath. $n$-Butyllithium (2.2 equiv, $1.6 \mathrm{M}$ ) in hexanes was added dropwise. The solution was stirred at $-78^{\circ} \mathrm{C}$ for 30 minutes and at RT for 2 hours. The solution was then cooled to $-78^{\circ} \mathrm{C}$ and freshly prepared trimethyltin chloride solution (2.4 equiv, $20 \%$ by wt. in THF) was added dropwise, and the solution was allowed to stir at RT overnight. The solution was poured into cold water and extracted with ether. The solution was washed with water, and the organic phase was dried over anhydrous $\mathrm{MgSO}_{4}$ and evaporated to give a waxy yellow solid ( $>95 \%$ yield). White powders could be obtained by triturating with EtOH. No difference in purity was observed via NMR spectroscopy, nor were there differences observed in subsequent polymerization reactions. 2,6-Bis(trimethyltin)-4,8-didodecyloxybenzo[1,2-b:4,5$\left.b^{\prime}\right]$ dithiophene (8). ${ }^{1} \mathrm{H}-\mathrm{NMR} \quad\left(\mathrm{CDCl}_{3}\right), \delta(\mathrm{ppm}): 7.52$ $(\mathrm{s}, 2 \mathrm{H}) ; 4.30(\mathrm{t}, 4 \mathrm{H}) ; 1.89(\mathrm{~m}, 4 \mathrm{H}) ; 1.59(\mathrm{~m}, 4 \mathrm{H})$; $1.23-1.43(\mathrm{~m}, 32 \mathrm{H}) ; 0.89(\mathrm{t}, 6 \mathrm{H}) ; 0.46(\mathrm{~s}, 18 \mathrm{H}) .{ }^{13} \mathrm{C}-$ NMR $\left(\mathrm{CDCl}_{3}\right), \delta(\mathrm{ppm}): 143.2,140.5,134.5,133.0$, $128.0, \quad 73.6, \quad 32.0, \quad 30.6, \quad 29.8,29.7,29.5, \quad 29.4,26.2$, 22.7, 14.2, $-8.3 .{ }^{119} \mathrm{Sn}-\mathrm{NMR}\left(\mathrm{CDCl}_{3}\right), \delta(\mathrm{ppm})$ relative to $\mathrm{SnMe}_{3} \mathrm{Cl}$ (164), -33.99. 2,6-Bis(trimethyltin)-4,8-bis(2ethylhexyloxy)benzo[1,2-b:4,5- $\left.b^{\prime}\right]$ dithiophene (9). ${ }^{1} \mathrm{H}-\mathrm{NMR}$ $\left(\mathrm{CDCl}_{3}\right), \delta(\mathrm{ppm}): 7.53(\mathrm{~s}, 2 \mathrm{H}) ; 4.20(\mathrm{~d}, 4 \mathrm{H}) ; 1.54-$ $1.64(\mathrm{~m}, 4 \mathrm{H}) ; 1.33-1.88(\mathrm{~m}, 18 \mathrm{H}) ; 1.04(\mathrm{t}, 6 \mathrm{H}) 0.96(\mathrm{t}$, $6 \mathrm{H}) 0.46(\mathrm{~s}, 18 \mathrm{H}),{ }^{13} \mathrm{C}-\mathrm{NMR}\left(\mathrm{CDCl}_{3}\right), \delta(\mathrm{ppm}): 143.3$, $140.4,133.9,132.9,128.0,75.7,40.7,30.6,29.3,24.0,23.2$, 14.2, 11.4, -8.3. ${ }^{119} \mathrm{Sn}-\mathrm{NMR}\left(\mathrm{CDCl}_{3}\right), \delta(\mathrm{ppm})$ relative to $\mathrm{SnMe}_{3} \mathrm{Cl}$ (164), -33.91. 2,6-Bis(trimethyltin)-4,8-bis(1ethylhexyloxy)benzo[1,2-b:4,5- $\left.b^{\prime}\right]$ dithiophene (10). ${ }^{1} \mathrm{H}-\mathrm{NMR}$ 
$\left(\mathrm{CDCl}_{3}\right), \delta(\mathrm{ppm}): 7.53(\mathrm{~s}, 2 \mathrm{H}) ; 4.58(\mathrm{~m}, 2 \mathrm{H}) ; 1.74(\mathrm{~m}, 8 \mathrm{H})$; $1.56(\mathrm{~m}, 6 \mathrm{H}) ; 1.33(\mathrm{~m}, 8 \mathrm{H}) ; 1.05(\mathrm{~m}, 6 \mathrm{H}) 0.90(\mathrm{~m}, 6 \mathrm{H}) 0.44$ $(\mathrm{s}, 18 \mathrm{H}) .{ }^{13} \mathrm{C}-\mathrm{NMR}\left(\mathrm{CDCl}_{3}\right), \delta(\mathrm{ppm}): 141.8,139.8,134.4$, 133.8, 128.7, 83.2, 33.7, 32.2, 27.0, 25.1, 22.7, 14.1, 9.7, -8.3. ${ }^{119} \mathrm{Sn}-\mathrm{NMR}\left(\mathrm{CDCl}_{3}\right), \delta(\mathrm{ppm})$ relative to $\mathrm{SnMe}_{3} \mathrm{Cl}(164)$, -34.18 .

2.3.6. General Procedure for Polymer Synthesis of P1-P3. Under ambient atmosphere in a $5 \mathrm{~mL}$ microwave tube equipped with a stir bar was added the bis(trimethyltin) monomer $(0.5 \mathrm{mmol})$ along with the dibromo monomer $(0.485 \mathrm{mmol})$ and $2 \mathrm{~mL}$ of chlorobenzene. The mixture was stirred for 5 minutes and tetrakis(triphenylphosphine)palladium(0) $(2.5-5 \mathrm{~mol} \%)$ was added to the tube and the tube was capped and set in the microwave at $200^{\circ} \mathrm{C}$ for 10 minutes. The viscous gel was precipitated in methanol and filtered. The solid was then added to a Soxhlet thimble and subjected to extractions with hexanes (6 hrs), THF (24 hrs), and finally chloroform (24 hrs). The chloroform extract was evaporated almost to completion, and methanol was added to precipitate the polymer, which was filtered and dried under vacuum for 24 hours.

2.3.7. Poly [(4,8-Bis(1-dodecyloxy)benzo[1,2-b:4,5- $\left.b^{\prime}\right]$ dithiophene-2,6-diyl-alt-2,1,3-benzothiadiazole-4,7-diyl] (P1). (Yield from $\mathrm{CHCl}_{3}$ extract, 5-30\%). FT-IR: 2917 (s), 2849 (s), $1577(\mathrm{~m}), 1524(\mathrm{~m}), 1489(\mathrm{~m}), 1450$ (s), $1400(\mathrm{~m}), 1354$ (s), 1273(m), 1177 (s), 1038 (br), 908 (m), 854 (m), 816 (s), $750(\mathrm{w}), 718(\mathrm{~m}), 689(\mathrm{~m})$. GPC (TCB, $\left.135^{\circ} \mathrm{C}\right): M_{n}=$ 4, $760 \mathrm{~g} / \mathrm{mol}, M_{w}=6,310 \mathrm{~g} / \mathrm{mol}, P D I=1.33 . \lambda_{\max }=598 \mathrm{~nm}$ (1,2-dichlorobenzene).

2.3.8. Poly[(4,8-bis(2-ethylhexyl)benzo[1,2-b:4,5- $\left.b^{\prime}\right]$ dithiophene-2,6-diyl-alt-2,1,3-benzothiadiazole-4,7-diyl] (P2). (Yield from $\mathrm{CHCl}_{3}$ extract, 5-20\%). FT-IR: 2951 (m), 2916 (s), 2850 (s), 1573 (m), 1523 (m), 1487 (m), 1447 (s), $1397(\mathrm{~m})$, 1351 (s), 1257 (w), 1175 (s), 1030 (br), 906 (m), 852 (w), 817 (s), $715(\mathrm{w}), 688(\mathrm{w})$. GPC (TCB, $\left.135^{\circ} \mathrm{C}\right): M_{n}=2,880 \mathrm{~g} / \mathrm{mol}$, $M_{w}=3,430 \mathrm{~g} / \mathrm{mol}, P D I=1.19 . \lambda_{\max }=579 \mathrm{~nm}(1,2-$ dichlorobenzene).

2.3.9. Poly[(4,8-bis(1-ethylhexyl)benzo[1,2-b:4,5- $\left.b^{\prime}\right]$ dithiophene-2,6-diyl-alt-2,1,3-benzothiadiazole-4,7-diyl] (P3). (Yield from $\mathrm{CHCl}_{3}$ extract, 40-56\%.) FT-IR: 2951 (m), 2916 (s), 2852 (s), 1575 (m), $1523(\mathrm{~m}), 1486(\mathrm{~m}), 1448$ (s), 1396 (m), 1337 (s), 1257 (w), 1178 (s), 1019 (br), 906 (m), $853(\mathrm{w}), 818(\mathrm{~s}), 715(\mathrm{w}), 688(\mathrm{w})$. GPC (TCB, $\left.135^{\circ} \mathrm{C}\right)$ : $M_{n}=27,100 \mathrm{~g} / \mathrm{mol}, M_{w}=68,800 \mathrm{~g} / \mathrm{mol}, P D I=2.54$. $\lambda_{\max }=637 \mathrm{~nm}$ (1,2-dichlorobenzene).

2.4. Electrochemistry. Cyclic voltammetry (CV) was carried out using a computer-controlled Pine Model AFCBP 1 BiPotentiostat with PineChem software in a standard singlecompartment, three electrode cell. The working electrode was glassy carbon, while the counter electrode was a platinum wire. The pseudoreference electrode was a silver wire and was calibrated against $\left(\mathrm{Fc} / \mathrm{Fc}^{+}\right)$. The polymer was drop-cast onto glassy carbon from a $2.5 \mathrm{mg} / \mathrm{mL}$ solution in chlorobenzene. All measurements were carried out in degassed solutions of acetonitrile with tetrabutylammonium hexafluorophosphate $(0.1 \mathrm{M}$, electrochemical grade) as the supporting electrolyte. The scan rate used was $100 \mathrm{mVs}^{-1}$. The electrochemical onsets were determined as the position at which the current differed by $2 \mu \mathrm{A}$ from the baseline. The highest occupied molecular orbital (HOMO) and lowest unoccupied molecular orbital (LUMO) energy levels were calculated from the oxidation $\left(E_{\text {onset }}^{\text {ox }}\right)$ and reduction $\left(E_{\text {onset }}^{\text {red }}\right)$ onsets, respectively, according to

$$
\begin{aligned}
& E_{\mathrm{HOMO}}=-\left(E_{\mathrm{onset}}^{\mathrm{ox}}+4.8\right)(\mathrm{eV}) \\
& E_{\mathrm{LUMO}}=-\left(E_{\text {onset }}^{\mathrm{red}}+4.8\right)(\mathrm{eV})
\end{aligned}
$$

2.5. Powder X-Ray Diffraction. X-Ray powder diffraction data were collected at room temperature using a BRUKER P4 general-purpose four-circle X-ray diffractometer modified with a GADDS/Hi-Star detector at $40 \mathrm{kv}$ and $30 \mathrm{~mA}$ for $\mathrm{Cu} \mathrm{K} \alpha$ radiation $(\lambda=1.5406 \AA)$. The GADDS software suite was used to control the goniometer [28]. The samples were mounted on a loop and two frames were measured at $2 \theta=20^{\circ}$ and $50^{\circ}$ with exposure time of 180 seconds/frame. For the inset powder diffraction spectrum, one frame was measured at $2 \theta=25^{\circ}$ with an exposure time of 180 seconds/frame for 10 frames. Area integration techniques were used to reproduce the single powder diffraction pattern for each frame. The powder patterns were each merged and analyzed using the EVA program to produce a single powder diffraction pattern [29].

2.6. Charge Transport Measurements. Bottom-contact thinfilm transistors (TFTs) were fabricated by spin-coating $(1000 \mathrm{rpm})$ polymer solutions $(0.75 \mathrm{wt} \%$ in 1,2 -dichlorobenzene) over the $1.2 \mathrm{~cm} \times 1.2 \mathrm{~cm}$ substrate with prefabricated device structures containing a Si gate electrode, $300 \mathrm{~nm}$ $\mathrm{SiO}_{2}$ gate dielectric and $5 \mathrm{~nm} \mathrm{Ti} / 45 \mathrm{~nm}$ Au source-drain contacts with channel length $L=5 \mu \mathrm{m}$ and channel width $W=1000 \mu \mathrm{m}$. Prior to spin coating, the substrates were cleaned by soaking in hot acetone, followed by isopropyl alcohol. The substrates were then cleaned in UV ozone for five minutes and rinsed with DI water. The surfaces were chemically treated by submerging the substrates for $30 \mathrm{~min}$ in a $17 \mathrm{mmol} \mathrm{n}$-octyltrichlorosilane (OTS) solution in hexadecane at room temperature. The substrates were then removed and sonicated in isopropyl alcohol for 10 minutes, sonicated in chloroform for 10 minutes, and rinsed with isopropyl alcohol followed by DI water. The polymer solutions were stirred overnight prior to spin coating to ensure complete dissolution. After spin-coating, the substrates were placed in a vacuum oven overnight prior to measuring the currentvoltage characteristics.

The transistors were characterized by measuring the drain current $\left(I_{\mathrm{D}}\right)$ against a sweeping gate voltage $\left(V_{\mathrm{GS}}\right)$ from $-20 \mathrm{~V}$ to $60 \mathrm{~V}$ in the saturation regime, drain source voltage $V_{\mathrm{DS}}=-60 \mathrm{~V}$. The measurements were made in ambient conditions using a commercially available probe station and an Agilent 4155C Semiconductor Parameter Analyzer. Five devices were measured for each material. The field-effect 
mobility $(\mu)$ was calculated from the slope of the $\left(I_{\mathrm{D}}\right)^{1 / 2}$ versus $V_{\mathrm{GS}}$ graph, using the relationship in

$$
I_{\mathrm{D}}=\frac{1}{2} \frac{W}{L} C_{i} \cdot \mu \cdot\left(V_{\mathrm{GS}}-V_{\mathrm{T}}\right)^{2},
$$

where $C_{i}$ is the capacitance per unit area for the $\mathrm{SiO}_{2}$ gate dielectric, $W$ is the channel width, $L$ is the channel length, and $V_{\mathrm{T}}$ is the threshold voltage. A value for $\partial I_{\mathrm{D}}^{1 / 2} / \partial V_{\mathrm{GS}}$ was determined from the slope of the linear portion of the $\left(I_{\mathrm{D}}\right)^{1 / 2}$ versus $V_{\mathrm{GS}}$ plot.

2.7. Photovoltaic Characteristics. ITO-coated glass slides (Delta Technologies) were cleaned by sonication in acetone and isopropanol for 20 minutes each, followed by ozone cleaning for 30 minutes. A solution of PEDOT: PSS (Clevios P-H.C. Starck) at 1:1 PEDOT: PSS solution to deionized water was spin-coated onto the slides at 4000 RPM (resulting in a $40 \mathrm{~nm}$ layer). The films were then baked in a vacuum oven at $100^{\circ} \mathrm{C}$ for 30 minutes. Polymer solutions were then spin-coated onto the PEDOT:PSS-coated substrates. Solutions were prepared by mixing polymer and 1,2dichlorobenzene $(8 \mathrm{mg} / \mathrm{mL}$ for $\mathbf{P} 2$ and $\mathbf{P 3}, 10 \mathrm{mg} / \mathrm{mL}$ for P1), then they were heated $\left(80^{\circ} \mathrm{C}\right.$ for $\mathbf{P 3}, 100^{\circ} \mathrm{C}$ for $\mathbf{P 1}$ and P3) and stirred for 24 hours. The solution for P3 was then filtered while hot $(0.45 \mu \mathrm{m}$ PVDF (Millipore)). P1 and P2 were spin-coated from unfiltered, hot solutions, since filtration removed much of the polymer and resulted in poorer device performance and a high frequency of devices shorting. Unfiltered solutions of $\mathbf{P} \mathbf{3}$ resulted in devices with $\sim 10 \%$ poorer power conversion efficiency. Optimal spin coating conditions were found to be 600 RPM for $30 \mathrm{~s}$ for P1 and P2, and 1500 RPM for $40 \mathrm{~s}$ for P3.

The films were set to dry for 30 minutes and then placed under vacuum for thermal deposition of electrodes ( $2 \mathrm{~nm} \mathrm{LiF/100} \mathrm{nm}$ aluminum). The active area of the device was $38 \mathrm{~mm}^{2}$. All film thicknesses were determined via a JEOL JSPM-5200 operating in AFM tapping mode.

The current-voltage $(J-V)$ characteristics were measured with a Keithley 236 digital source meter under simulated air mass (AM) 1.5 solar irradiation of $100 \mathrm{~mW} / \mathrm{cm}^{2}$ (Oriel $150 \mathrm{~W}$ Xenon Light Source). The light intensity was calibrated with a NREL calibrated reference cell (Newport). The external quantum efficiency (EQE) curve was measured using a $300 \mathrm{~W}$ Oriel Xenon light source passed through an Oriel Cornerstone 260 monochromator, a Merlin lock-in amplifier, a calibrated Si UV detector, and an SR 570 low noise preamplifier.

\section{Results and Discussion}

3.1. Synthesis and Characterization. The synthetic routes to the monomers and polymers are shown in Scheme 2. Starting from 3-thiophenecarboxylic acid (1), we developed a new one-pot procedure for accessing the synthetic intermediate $\mathrm{N}, \mathrm{N}$-diethylthiophene-3-carboxamide (3). This involves the in situ preparation of thiophene-3-carbonyl chloride (2) via the reaction of $\mathbf{1}$ with thionyl chloride and excess triethylamine in dichloromethane. The triethylamine functions as a catalyst by generating the more reactive carboxylate and also reacts with the hydrochloric acid $(\mathrm{HCl})$ byproduct generated by the chlorination reaction. After 30 minutes of stirring, a single equivalent of diethylamine was added to the reaction mixture containing 2 to form the desired product. The $\mathrm{HCl}$ generated by this reaction was reacted with the remaining triethylamine. The dione 4 , the 4,8 -dialkoxy-BDTs (5-7) and the bis-stannane monomers $(8-10)$ are prepared by procedures similar to those in the literature $[18,21]$. The purity of monomers $\mathbf{8 - 1 0}$ was confirmed by ${ }^{119} \mathrm{Sn}-$ NMR spectroscopy (See Supplementary Materials available at doi:10.1155/2011/572329) a very useful technique for determining whether there are any trace monostannane impurities in the monomers. These impurities are detrimental to molecular weight growth.

The polymers P1-P3 were prepared by microwaveassisted Stille cross-coupling polymerization of the bisstannane monomers 8-10 with 4,7-dibromo-2,1,3-benzothiadiazole (BT) in chlorobenzene using tetrakis(triphenylphosphine)palladium $(0)\left(\left(\mathrm{Ph}_{3} \mathrm{P}\right)_{4} \mathrm{Pd}\right)$ as the catalyst (see Scheme 1). Microwave heating was used because it is more efficient than conventional heating methods, and it has also been reported to give higher molecular weights $[19,22$, 30-32]. After reaction the polymers were precipitated into methanol, collected by filtration, and transferred to a Soxhlet extractor where the material was washed with hexanes and extracted with chloroform. The chloroform-soluble fraction was isolated to ensure the material was sufficiently soluble for the preparation OPV devices. In all cases, material remained in the extraction thimble after chloroform extraction; however, the amount of this material was highly variable. For P1 and $\mathbf{P} 2$, yields from the chloroform soluble fractions were often less than $10 \%$, while for P3, yields as high as $55 \%$ were obtained. Assuming no crosslinking has occurred, the fact that material remained in the extraction thimble after chloroform extraction means that the chloroform fraction contained material with the highest molecular weight that is soluble in chloroform. The molecular weights of the these fractions were determined by gel permeation chromatography (GPC) at $135^{\circ} \mathrm{C}$ using 1,2,4-trichlorobenzene as the solvent, and the results are summarized in Table 1. P1, P2, and P3 were found to have weight average molecular weights $\left(M_{w}\right)$ of $6.3,3.4$, and $68.8 \mathrm{~kg} / \mathrm{mol}$, respectively. Our result for P1 differs dramatically from that of Hou et al. and may be due to differences in GPC protocols. Hou et al. ran elutions at RT using THF and found a $M_{w}$ of $31.4 \mathrm{~kg} / \mathrm{mol}$, while our GPC protocol was $135^{\circ} \mathrm{C}$ using 1,2,4-trichlorobenzene as eluent and found our $M_{w}$ to be $6.3 \mathrm{~kg} / \mathrm{mol}$. For P2, we find that despite several reports of the beneficial effect of the 2ethylhexyl side chain on solubility and molecular weight, P2 has a lower $M_{w}$ than P1. Lastly we find that moving the ethyl branch in by one position (P2 compared with $\mathbf{P} 3$ ) results in an unexpectedly large increase in $M_{w}$.

Thermogravimetric analysis (TGA) was performed on polymers P1-P3 under argon at $5^{\circ} \mathrm{C} / \mathrm{min}$ as shown in Figure 1. The results indicate that the polymers have similar thermal stabilities with the onsets of degradation ranging from $268^{\circ} \mathrm{C}$ and $278^{\circ} \mathrm{C}$. This degradation has been attributed to the loss of the side chains [18], which is supported by the 

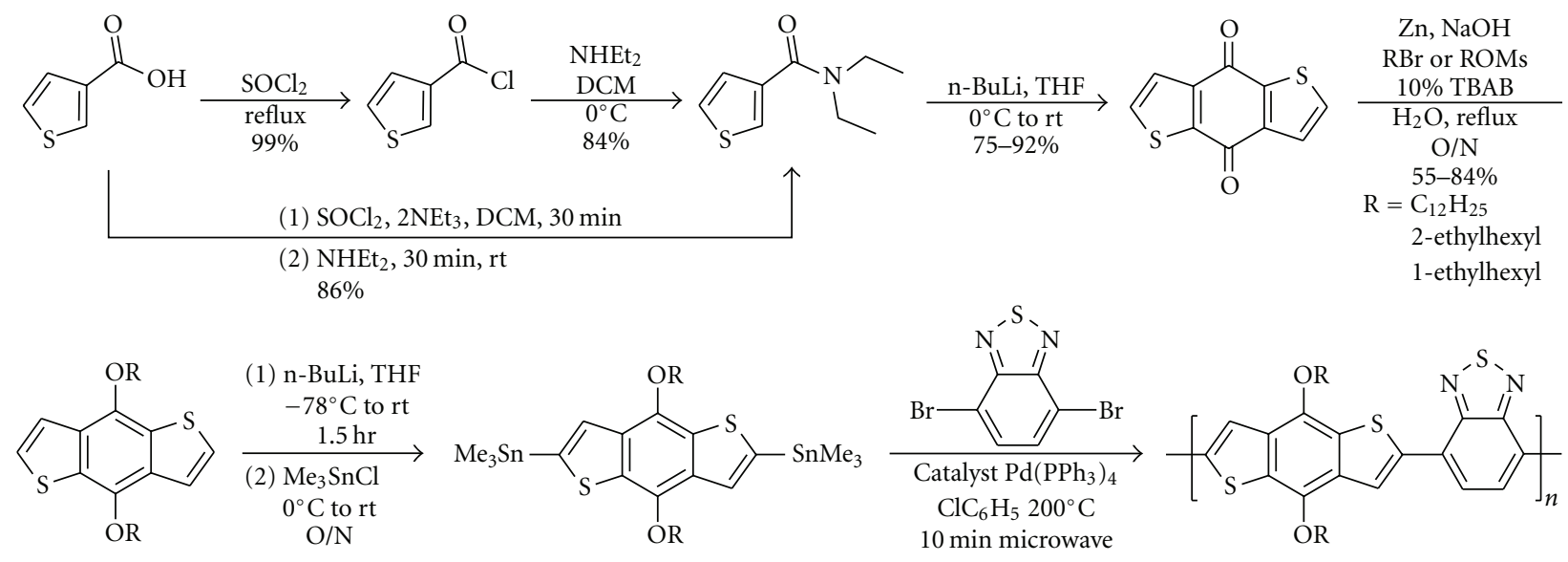

Scheme 2: Synthesis of 4,8-dialkoxybenzo[1,2-b:4,5-b'] dithiophene (BDT) 2,1,3-benzothiadiazole copolymers.

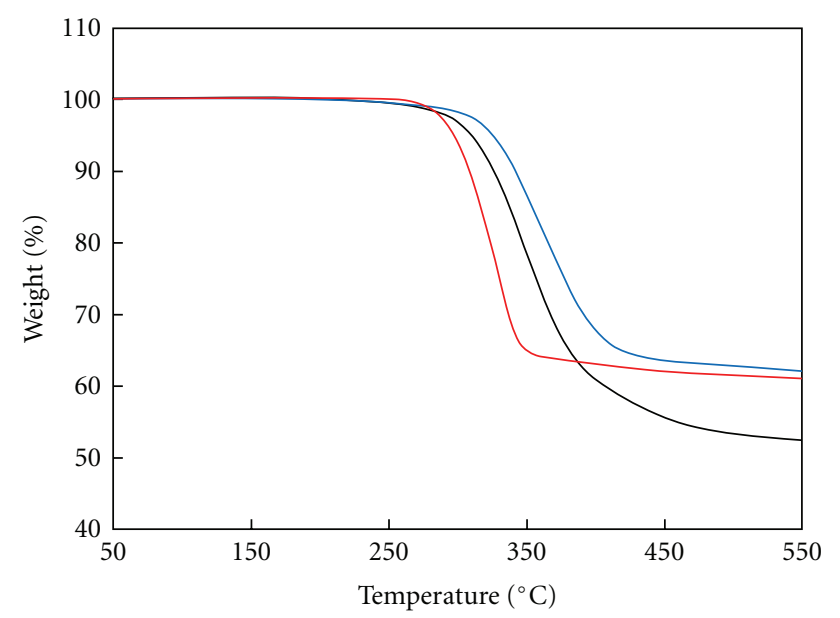

Figure 1: TGA curves of P1 (black), P2 (blue), and P3 (red) under argon at a heating rate of $5^{\circ} \mathrm{C} / \mathrm{min}$.

fact that the $\mathbf{P} \mathbf{1}$ which has 12 carbon side chain loses a larger weight percentage compared with $\mathbf{P} 2$ and $\mathbf{P 3}$, which have 8 carbon side chains.

3.2. Optical and Electrochemical Properties. UV-visible absorption spectra (normalized by area) for polymers P1P3 in chloroform solution are shown in Figure 2. P2 is considerably blue-shifted of P1, with a $\lambda_{\max }$ of $579 \mathrm{~nm}$ compared to $598 \mathrm{~nm}$ for $\mathbf{P 1}$. The spectrum for $\mathbf{P} \mathbf{1}$ is similar in shape and slightly red-shifted of Hou et al.'s H7 $\left(\lambda_{\max }=\right.$ $591 \mathrm{~nm}$ in THF) indicating comparable molecular weight. The shape of the absorption profile for $\mathbf{P} \mathbf{3}$ is very different from those of $\mathbf{P} \mathbf{1}$ and $\mathbf{P} 2$ with a very sharp low-energy feature dominating the spectrum-resulting in a $\lambda_{\max }$ of $637 \mathrm{~nm}$ for P3. This sharp low-energy feature has been seen in other low bandgap copolymers and is indicative of high molecular weight and often high solar cell performance $[11,19,33$, 34]. UV-Vis spectra of $\mathbf{P 1}$ and $\mathbf{P} 3$ films (dropcast from chloroform) are shown in the dashed spectra in Figure 2. A spectrum for $\mathbf{P} 2$ is not shown as dewetting of the chloroform

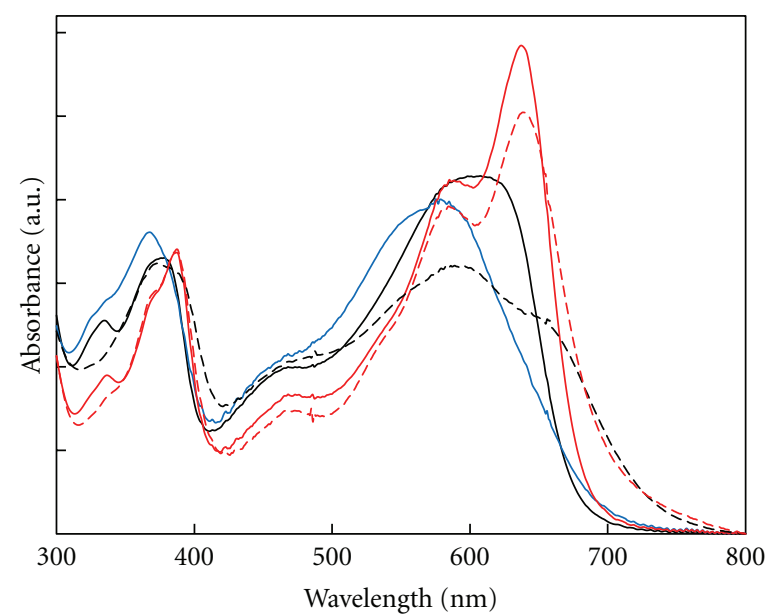

Figure 2: UV-Vis spectra of P1 (black), P2 (blue), and P3 (red) in chloroform solution (solid) and film (dashed). Spectra are normalized by area.

TABLE 1: Molecular weight of the polymers.

\begin{tabular}{lccc}
\hline & $M_{n}(\mathrm{~kg} / \mathrm{mol})$ & $M_{w}(\mathrm{~kg} / \mathrm{mol})$ & $P D I$ \\
\hline P1 & 4.8 & 6.3 & 1.33 \\
P2 & 2.9 & 3.4 & 1.19 \\
P3 & 27.1 & 68.8 & 2.54 \\
\hline
\end{tabular}

solution prevented preparation of uniform film. The onset of absorption for $\mathbf{P} 1$ red shifts $45 \mathrm{~nm}$ transitioning from $685 \mathrm{~nm}$ in solution to $730 \mathrm{~nm}$ in the film. The shift in absorption onset for P3 is not as large, shifting $35 \mathrm{~nm}$ from $695 \mathrm{~nm}$ in solution to $730 \mathrm{~nm}$ in the film. The film spectrum for P1 shows the presence of low-energy shoulder that was not observed in solution, while the spectrum for P3 is broadened but similar in shape to the solution spectrum. The optical bandgaps for both $\mathbf{P 1}$ and $\mathbf{P} \mathbf{3}$ as determined by absorption onset is $1.69 \mathrm{eV}$.

Cyclic voltammetry measurements were made on polymer films of $\mathbf{P 1 - P 3}$ prepared by dropcasting chloroform 
TABLE 2: Summary of optical and electrochemical properties.

\begin{tabular}{lccccccc}
\hline & $\lambda_{\max }(\mathrm{nm})$ & $E_{g}^{\text {opt }}(\mathrm{eV})$ & $E_{\text {onset }}^{\text {ox }}(\mathrm{V})$ & HOMO $(\mathrm{eV})$ & $E_{\text {onset }}^{\text {red }}(\mathrm{V})$ & LUMO $(\mathrm{eV})$ & $E_{g}^{\text {elect }}(\mathrm{eV})$ \\
\hline P1 & 598 & 1.69 & 0.15 & -4.95 & -1.72 & -3.08 & 1.87 \\
P2 & 579 & - & 0.13 & -4.93 & -1.62 & -3.18 & 1.75 \\
P3 & 637 & 1.69 & 0.12 & -4.92 & -1.59 & -3.21 & 1.71 \\
\hline
\end{tabular}

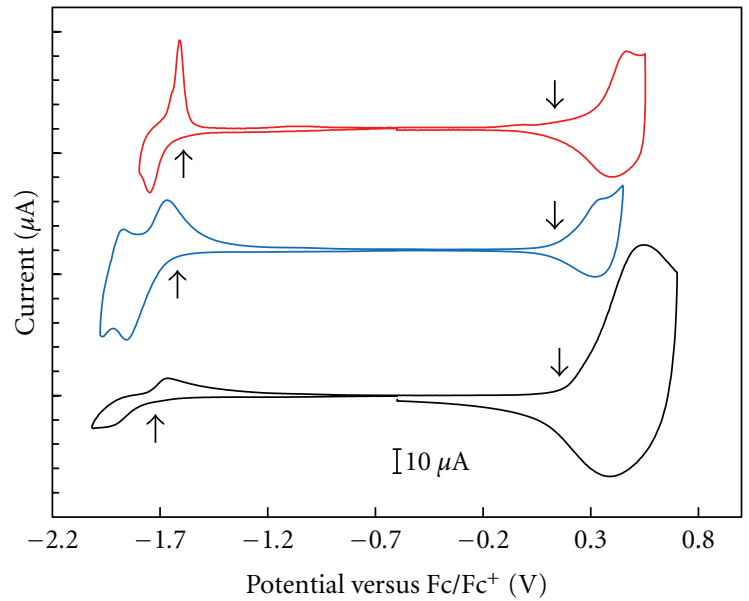

Figure 3: Cyclic voltammograms of P1 (black), P2 (blue), and P3 (red). Arrows indicate onsets.

solutions of the polymers onto a glassy carbon electrode (see Figure 3). The onsets of the oxidation and reduction potentials for the three polymers were comparable-not surprising given that they share a common backbone. These results are summarized in Table 2. The oxidation onsets, determined as the point where the current differed from the baseline by $2 \mu \mathrm{A}$, were found to be $0.15,0.13$, and $0.12 \mathrm{~V}$ for $\mathbf{P 1}, \mathbf{P 2}$, and $\mathbf{P 3}$ giving rise to HOMO levels of -4.95 ([18] $-5.10 \mathrm{eV}),-4.93$, and $-4.92 \mathrm{eV}$, respectively. Similarly, the reduction onsets were found to be $-1.72,-1.62$ and $-1.59 \mathrm{~V}$ for P1, P2, and P3 giving rise to LUMO levels of -3.08 ([18] $-3.19 \mathrm{eV}),-3.18$, and $-3.21 \mathrm{eV}$, respectively. These results give electrochemical bandgaps of 1.87 ([18] $1.91 \mathrm{eV}), 1.75$, and $1.71 \mathrm{eV}$ for $\mathbf{P 1}, \mathbf{P} 2$, and $\mathbf{P 3}$.

3.3. Solid State Ordering and Charge Transport. To give insight into the internal packing structure of the polymers, powder X-ray diffraction (PXRD) was used. Samples were mounted on a loop and two frames were measured at $2 \theta=20$ and $50^{\circ}$ with exposure time of 180 seconds/frame. The integrated diffraction patterns are shown in Figure 4(a). For the inset powder diffraction pattern, 10 frames were measured at $2 \theta=25^{\circ}$ with an exposure time of 180 seconds/frame, then they were added together. The intensities of the diffraction patterns decrease and diffraction peaks broaden from P1 to $\mathbf{P} 2$ to $\mathbf{P 3}$, indicating that structural order within the solid polymers decreases in the order $\mathbf{P 1}>\mathbf{P} 2>\mathbf{P}$ 3. This order correlates with the increasing bulk of the side chain relative to the conjugated backbone. For P3, which has a much higher $M_{w}$, this lack of order is further exacerbated, since order has been shown to decrease as $M_{w}$ increases [35].
The peaks at low angle $\left(2 \theta=4.15^{\circ}\right.$ for $\mathbf{P} 1,5.7^{\circ}$ for $\mathbf{P} 2$ and $5.5^{\circ}$ for $\mathbf{P 3}$ ) are assigned to the intermolecular distance between the polymer main chains separated by an alkoxy side chain $\left(d_{1}\right.$-spacing; see Figure $\left.4(\mathrm{~b})\right)$. The dodecyloxy chain (P1) gives the longest $d_{1}$-spacing at $21.3 \AA$, while the shorter 2-ethylhexyloxy (P2) and 1-ethylhexyloxy (P3) side chains give small $d_{1}$-spacings (15.5 and $16.1 \AA$, resp.). A plot of the low angle d-spacing versus no. of carbon atoms for the three polymers gave a slope of $0.98 \AA /$ carbon atom, which is indicative of an interdigitation packing mode (see Figure 4(b)), not an end-to-end packing mode like that seen in polythiophenes [36-38]. The peaks at $2 \theta=24.9^{\circ}$ for $\mathbf{P 1}, 24.5^{\circ}$ for $\mathbf{P} 2$ and $23.8^{\circ}$ for $\mathbf{P} 3$ correspond to the $\pi-\pi$ stacking distances ( $d_{2}$-spacings) $3.58,3.63$, and $3.74 \AA$ for P1, P2, and P3, respectively. Despite the increase in the $\pi$ $\pi$ stacking distance due to the 1-ethylhexyl chain, it is worth noting that $\mathbf{P} 3$ still has a smaller $\pi-\pi$ stacking distance than poly(3-hexylthiophene).

Thin-film transistors were fabricated from the three polymers to assess charge transport. Figure 5 shows the current-voltage characteristics of a representative device for each polymer with channel length $L=5 \mu \mathrm{m}$ and channel width $W=1000 \mu \mathrm{m}$. Here, we plot the $\log \left(I_{\mathrm{D}}\right)$ versus $V_{\mathrm{GS}}$ in solid symbols (right axis) and the $\left(I_{\mathrm{D}}\right)^{1 / 2}$ versus $V_{\mathrm{GS}}$ in open symbols (left axis) in the saturation regime $\left(V_{\mathrm{DS}}=\right.$ $-60 \mathrm{~V})$. The field-effect hole mobility $\left(\mu_{h}\right)$ of the devices shown here are $\mu_{h}=1.36 \times 10^{-6}, 9.69 \times 10^{-7} \mathrm{~cm}^{2} / \mathrm{Vs}$ and $8.17 \times 10^{-4} \mathrm{~cm}^{2} / \mathrm{Vs}$ for $\mathbf{P 1}, \mathbf{P} 2$, and $\mathbf{P}$ 3, respectively. These values represent an underestimation of the mobility of these materials, as optical inspection of the devices demonstrated that the film partially dewets the substrates, and the material covers only a fraction of the width of the device. Thus the real width in (3) is lower than the width defined by photolithography. The on/off current ratios for the three devices presented here are $10^{2}, 10^{2}$, and $10^{4}$, for $\mathbf{P 1}, \mathbf{P} 2$, and P3, respectively.

3.4. Photovoltaic Properties. The photovoltaic characteristics of the polymers were determined using a standard bulk heterojunction device architecture-ITO/PEDOT: PSS/P1P3 : $\mathrm{PC}_{61} \mathrm{BM} / \mathrm{LiF} / \mathrm{Al}$. The devices $\left(0.38 \mathrm{~cm}^{2}\right)$ were fabricated under an inert atmosphere and tested in air. The active layers were deposited from 1,2-dichlorobenzene solutions $(8 \mathrm{mg} / \mathrm{mL}$ for $\mathbf{P} \mathbf{2}$ and $\mathbf{P} \mathbf{3}, 10 \mathrm{mg} / \mathrm{mL}$ for $\mathbf{P 1}$ ) and the optimal weight ratios of polymer: $\mathrm{PC}_{61} \mathrm{BM}$ was determined to be $1: 2.5$ for $\mathbf{P} 1$ and $\mathbf{P} 3$ and $1: 2.2$ for $\mathbf{P} 2$. The active layer thickness for the optimal devices as determined by atomic force microscopy (AFM) were 130, 50, and $100 \mathrm{~nm}$ for P1, $\mathbf{P 2}$, and $\mathbf{P 3}$, respectively. Due to the poor solubility of $\mathbf{P 2}$ and its low $M_{w}$, thicker films could not be achieved even at the lowest spin speeds. The current-voltage curves for the 


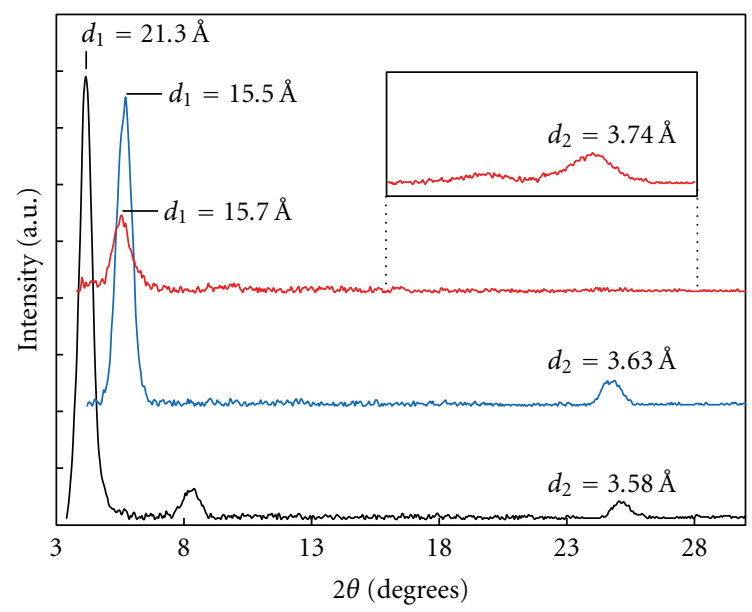

(a)

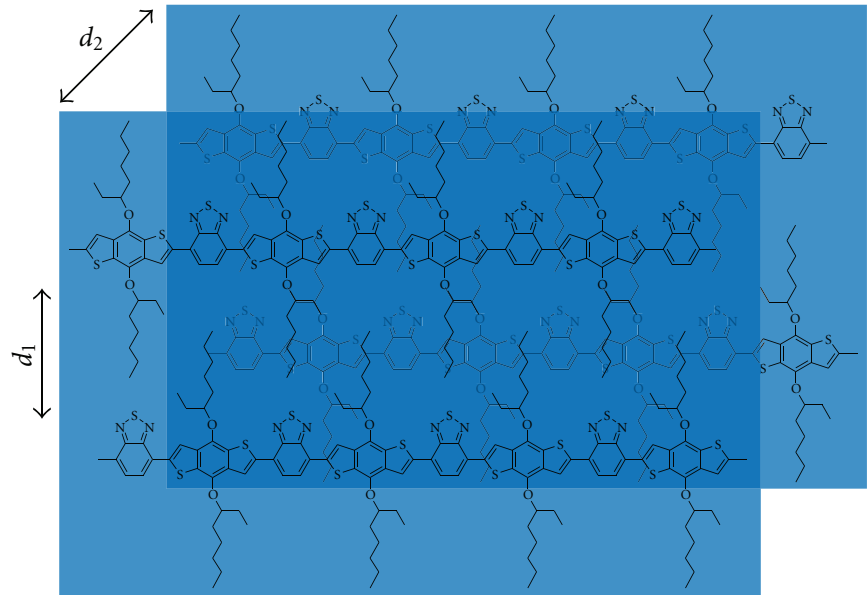

(b)

Figure 4: (a) Integrated powder diffraction patterns for P1 (black), P2 (blue), and P3 (red). Inset: 10 frames added together for P3. (b) Model of packing for $\mathbf{P}$.

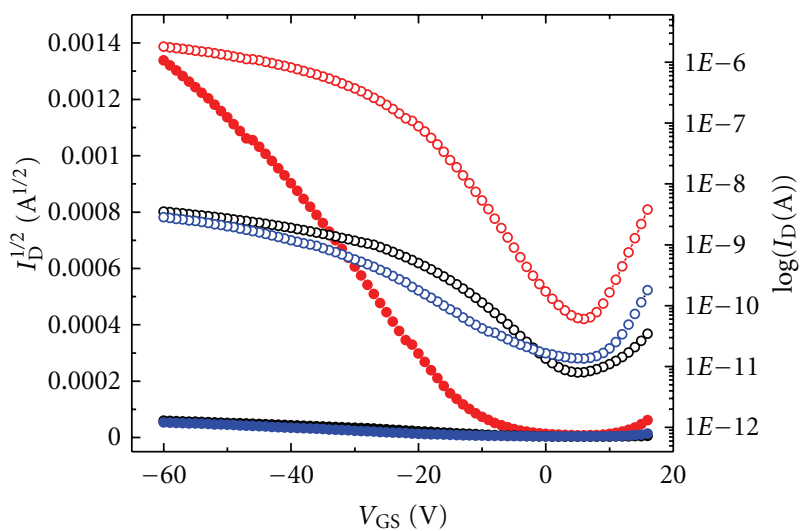

Figure 5: Electrical characteristics of P1 (black), P2 (blue), and P3 (red). Each device has dimensions $L=5 \mu \mathrm{m}$ and $W=1000 \mu \mathrm{m}$. A plot of the $\log \left(I_{\mathrm{D}}\right)$ versus $V_{\mathrm{GS}}$ in open symbols (right axis) and the $I_{\mathrm{D}}^{1 / 2}$ versus $V_{\mathrm{GS}}$ in solid symbols (left axis) in the saturation regime $\left(V_{\mathrm{DS}}=-60 \mathrm{~V}\right)$ are shown.

best devices for each polymer are shown in Figure 6, and the results are summarized in Table 3.

Consistent with the HOMO levels determined by cyclic voltammetry, the open circuit voltages $\left(V_{\text {oc }}\right)$ are similar for the three polymers, near $0.7 \mathrm{~V}$. The short circuit currents $\left(J_{\text {sc }}\right)$ for $\mathbf{P 1}$ and $\mathbf{P 2}$ are similarly low (near $1 \mathrm{~mA} / \mathrm{cm}^{2}$ ), while it is much higher for $\mathbf{P} 3$ at $8.93 \mathrm{~mA} / \mathrm{cm}^{2}$. The fill factors (FFs) increase with increasing $M_{w}$ peaking at 0.46 for P3. Consequently, P3 has a much higher power conversion efficiency (PCE) peaking at $2.91 \%$ compared with $0.31 \%$ for $\mathbf{P 1}$ and $0.19 \%$ for $\mathbf{P} 2$.

The EQE spectra for the $\mathbf{P} \mathbf{1}$ and $\mathbf{P} \mathbf{2}$ devices (seen in Figure 7) show poor current generation across the spectrum with peak EQE less than $12 \%$. P3, on the other hand, shows EQE above $30 \%$ from $330-670 \mathrm{~nm}$, with a peak at $51 \%$ at $370 \mathrm{~nm}$. Between 400 and $600 \mathrm{~nm}$, the EQE dips, indicating that current production could be enhanced by using $\mathrm{PC}_{71} \mathrm{BM}$

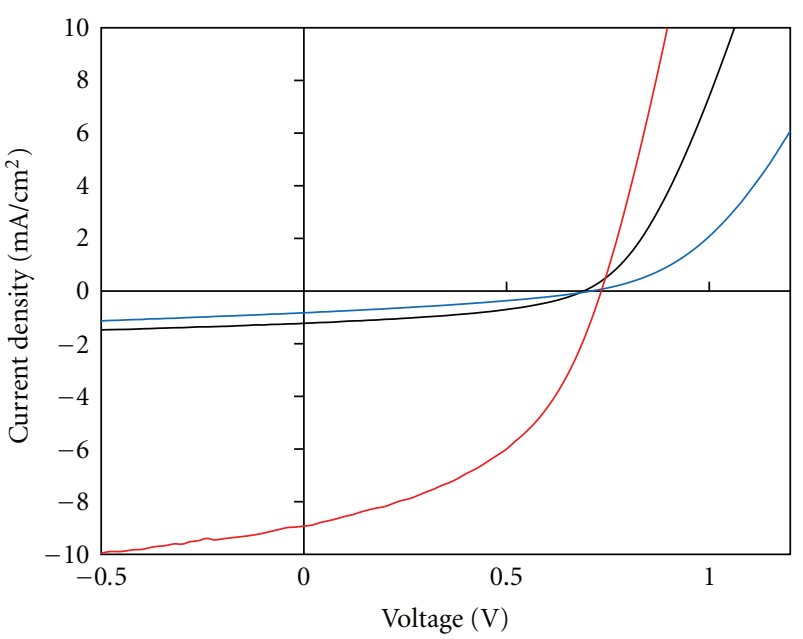

Figure 6: Current-voltage characteristics of bulk heterojunction solar cells based on P1 (black), P2 (blue), and P3 (red) and $\mathrm{PC}_{61} \mathrm{BM}$.

TABLE 3: Photovoltaic characteristics of best devices prepared from P1-P3 and $\mathrm{PC}_{61} \mathrm{BM}$ at a polymer.

\begin{tabular}{lcccc}
\hline & $V_{\text {oc }}(\mathrm{V})$ & $J_{\text {sc }}\left(\mathrm{mA} / \mathrm{cm}^{2}\right)$ & FF & PCE $(\%)$ \\
\hline P1 & 0.69 & 1.22 & 0.42 & 0.33 \\
P2 & 0.71 & 0.81 & 0.33 & 0.19 \\
P3 & 0.73 & 8.93 & 0.46 & 2.99 \\
\hline
\end{tabular}

instead of $\mathrm{PC}_{61} \mathrm{BM}$ as $\mathrm{PC}_{71} \mathrm{BM}$ absorbs in this range [26]. $\mathrm{A}$ comparison between these devices fabricated from P1 with Hou et al.'s $\mathbf{H 7}$ [18] reveals similar $V_{\text {oc }}$ 's $(0.69 \mathrm{~V}$ for $\mathbf{P 1}$ versus $0.68 \mathrm{~V}$ for $\mathrm{H} 7$ ) and $\mathrm{FFs}(0.42$ versus 0.44$)$ though they obtain a higher $J_{\text {sc }}$ of $2.97 \mathrm{~mA} / \mathrm{cm}^{2}$ resulting in a higher PCE of $0.90 \%$. The discrepancy in results could be explained by the fact that Hou et al. used a $\mathrm{Ca} / \mathrm{Al}$ cathode and tested the devices under nitrogen, whereas we used a $\mathrm{LiF} / \mathrm{Al}$ cathode and tested in air. $\mathbf{P} \mathbf{3}$ outperforms $\mathbf{H} \mathbf{7}$ across the board, with 


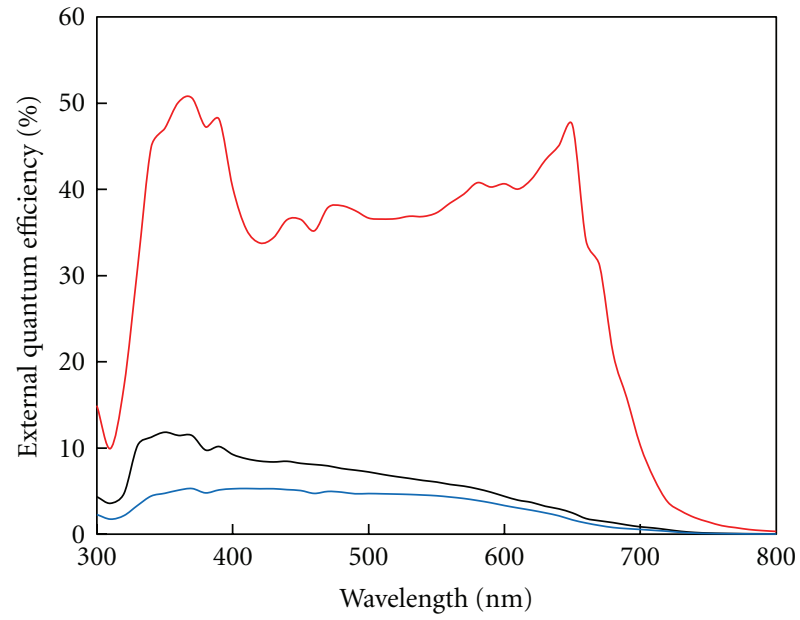

Figure 7: External quantum efficiency spectra of bulk heterojunction solar cells based on P1 (black), P2 (blue), and P3 (red) and $\mathrm{PC}_{61} \mathrm{BM}$.

higher $V_{\mathrm{oc}}, J_{\mathrm{sc}}, \mathrm{FF}$, and PCE, highlighting the significance of our side chain variation. It is worth noting that the $\mathbf{P} 3$ solar cells were prepared from pristine DCB solution without the use of optimization techniques such as annealing or additive processing that could greatly enhance the PCE.

\section{Conclusions}

We prepared and characterized two new low bandgap copolymers based on BDT and BT that employ branched side chains at the 4 and 8 positions, poly[(4,8-bis(2ethylhexyloxy)benzo[1,2-b:4,5-b'] dithiophene- 2,6-diyl-alt2,1,3-benzothiadiazole-4,7-diyl $]$ (P2) and poly[(4,8-bis(1ethylhexyloxy)benzo[1,2-b:4,5-b' ] dithiophene-2,6-diyl-alt2,1,3-benzothiadiazole-4,7-diyl] (P3) as well as the previously reported linear side chain analog poly[ $(4,8$-didodecyloxy ) benzo [1,2-b:4,5-b'] dithiophene-2,6-diyl-alt-2,1, 3-benzothiadiazole-4,7-diyl] (P1).Surprisingly, transitioning from the linear dodecyl side chain (P1) to the branched 2-ethylhexyl side chain (P2) results in a decrease in $M_{w}$; however, by moving the ethyl branch in by one position relative to the polymer backbone (P3), we observe a dramatic increase in $M_{w}$ to $68.8 \mathrm{~kg} / \mathrm{mol}$ compared with $6.3 \mathrm{~kg} / \mathrm{mol}$ for $\mathbf{P 1}$ and $3.4 \mathrm{~kg} / \mathrm{mol}$ for $\mathbf{P 2}$. This results in vastly different optical properties, with the appearance of a sharp low-energy feature in the UV-visible absorption spectrum of P3 that is not present in the spectra of $\mathbf{P 1}$ and $\mathbf{P} 2$. Despite the increase in the $\pi-\pi$ stacking distance due to the 1-ethylhexyl branch in $\mathbf{P} 3$ relative to $\mathbf{P} 1$ and $\mathbf{P} 2$, the increased $M_{w}$ results in a factor of 100 increase in hole mobility, and a factor of 10 increase in the PCE of bulk heterojunction solar cells. We observe a peak PCE of $2.91 \%$ for devices based on P3 and $\mathrm{PC}_{61} \mathrm{BM}$ with minimal optimization indicating that this material has the potential to make highly efficient solar cells. The use of the 1-ethylhexyl side chain, and indeed, the general technique of moving side chain branches closer to the polymer backbone is a widely applicable means of increasing $M_{w}$ in conjugated polymers, many of which have not reached their full potential because of insufficient $M_{w}$.

\section{Acknowledgments}

This work was supported by grants from FiberCell Inc. and the Department of Energy (DOE DE-FG02-07ER46428).

\section{References}

[1] W. Cai, X. Gong, and Y. Cao, "Polymer solar cells: recent development and possible routes for improvement in the performance," Solar Energy Materials and Solar Cells, vol. 94, no. 2, pp. 114-127, 2010.

[2] S. Günes, H. Neugebauer, and N. S. Sariciftci, "Conjugated polymer-based organic solar cells," Chemical Reviews, vol. 107, no. 4, pp. 1324-1338, 2007.

[3] B. C. Thompson and J. M. J. Fréchet, "Polymer-fullerene composite solar cells," Angewandte Chemie, vol. 47, no. 1, pp. 5877, 2008.

[4] L. Li, G. Lu, X. Yang, and E. Zhou, "Progress in polymer solar cell," Chinese Science Bulletin, vol. 52, no. 2, pp. 145-158, 2007.

[5] K. M. Coakley and M. D. McGehee, "Conjugated polymer photovoltaic cells," Chemistry of Materials, vol. 16, no. 23, pp. 4533-4542, 2004.

[6] J. Y. Kim, K. Lee, N. E. Coates et al., "Efficient tandem polymer solar cells fabricated by all-solution processing," Science, vol. 317, no. 5835, pp. 222-225, 2007.

[7] Press Release, 2010, http://www.konarka.com/.

[8] J. K. Lee, W. L. Ma, C. J. Brabec et al., "Processing additives for improved efficiency from bulk heterojunction solar cells," Journal of the American Chemical Society, vol. 130, no. 11, pp. 3619-3623, 2008.

[9] J. Peet, C. Soci, R. C. Coffin et al., "Method for increasing the photoconductive response in conjugated polymer/fullerene composites," Applied Physics Letters, vol. 89, no. 25, Article ID 252105, 2006.

[10] Y. Kim, S. A. Choulis, J. Nelson, D. D. C. Bradley, S. Cook, and J. R. Durrant, "Device annealing effect in organic solar cells with blends of regioregular poly(3-hexylthiophene) and soluble fullerene," Applied Physics Letters, vol. 86, no. 6, Article ID 063502, pp. 1-3, 2005.

[11] J. Peet, J. Y. Kim, N. E. Coates et al., "Efficiency enhancement in low-bandgap polymer solar cells by processing with alkane dithiols," Nature Materials, vol. 6, no. 7, pp. 497-500, 2007.

[12] F. Padinger, R. S. Rittberger, and N. S. Sariciftci, "Effects of postproduction treatment on plastic solar cells," Advanced Functional Materials, vol. 13, no. 1, pp. 85-88, 2003.

[13] M. Campoy-Quiles, T. Ferenczi, T. Agostinelli et al., "Morphology evolution via self-organization and lateral and vertical diffusion in polymer:fullerene solar cell blends," Nature Materials, vol. 7, no. 2, pp. 158-164, 2008.

[14] J. S. Moon, C. J. Takacs, S. Cho et al., "Effect of processing additive on the nanomorphology of a bulk heterojunction material," Nano Letters, vol. 10, no. 10, pp. 4005-4008, 2010.

[15] M. Lenes, G. J. A. H. Wetzelaer, F. B. Kooistra, S. C. Veenstra, J. C. Hummelen, and P. W. M. Blom, "Fullerene bisadducts for enhanced open-circuit voltages and efficiencies in polymer solar cells," Advanced Materials, vol. 20, no. 11, pp. 2116-2119, 2008.

[16] Y. He, H. Y. Chen, J. Hou, and Y. Li, "Indene-C bisadduct: a new acceptor for high-performance polymer solar cells," Journal of the American Chemical Society, vol. 132, no. 4, pp. 1377$1382,2010$. 
[17] Y. J. Cheng, S. H. Yang, and C. S. Hsu, "Synthesis of conjugated polymers for organic solar cell applications," Chemical Reviews, vol. 109, no. 11, pp. 5868-5923, 2009.

[18] J. Hou, M. H. Park, S. Zhang et al., "Bandgap and molecular energy level control of conjugated polymer photovoltaic materials based on benzo[1,2-b:4,5- $\left.b^{\prime}\right]$ dithiophene," Macromolecules, vol. 41, no. 16, pp. 6012-6018, 2008.

[19] R. C. Coffin, J. Peet, J. Rogers, and G. C. Bazan, "Streamlined microwave-assisted preparation of narrow-bandgap conjugated polymers for high-performance bulk heterojunction solar cells," Nature Chemistry, vol. 1, no. 8, pp. 657-661, 2009.

[20] Y. Liang, D. Feng, Y. Wu et al., "Highly efficient solar cell polymers developed via fine-tuning of structural and electronic properties," Journal of the American Chemical Society, vol. 131, no. 22, pp. 7792-7799, 2009.

[21] J. Hou, H. Y. Chen, S. Zhang et al., "Synthesis of a low band gap polymer and its application in highly efficient polymer solar cells," Journal of the American Chemical Society, vol. 131, no. 43, pp. 15586-15587, 2009.

[22] H. Zhou, L. Yang, S. C. Price, K. J. Knight, and W. You, "Enhanced photovoltaic performance of low-bandgap polymers with deep LUMO levels," Angewandte Chemie, vol. 49, no. 43, pp. 7992-7995, 2010.

[23] C. Piliego, T. W. Holcombe, J. D. Douglas, C. H. Woo, P. M. Beaujuge, and J. M. J. Fréchet, "Synthetic control of structural order in $\mathrm{N}$-alkylthieno[3,4- c]pyrrole-4,6-dione-based polymers for efficient solar cells," Journal of the American Chemical Society, vol. 132, no. 22, pp. 7595-7597, 2010.

[24] Y. Liang, Z. Xu, J. Xia et al., "For the bright future-bulk heterojunction polymer solar cells with power conversion efficiency of 7.4\%," Advanced Materials, vol. 22, no. 20, pp. E135-E138, 2010.

[25] H.-Y. Chen, J. Hou, S. Zhang et al., "Polymer solar cells with enhanced open-circuit voltage and efficiency," Nature Photonics, vol. 3, no. 11, pp. 649-653, 2009.

[26] Y. Zou, A. Najari, P. Berrouard et al., "A thieno[3,4- c ]pyrrole4,6-dione-based copolymer for efficient solar cells," Journal of the American Chemical Society, vol. 132, no. 15, pp. 5330-5331, 2010.

[27] K. Pilgram, M. Zupan, and R. Skiles, "Bromination of 2,1,3benzothiadiazoles," Journal of Heterocyclic Chemistry, vol. 7, p. 629, 1970.

[28] GADDS V4.1.14, General Area Detector Diffraction System Program for Instrument Control and Data Collection, BRUKER AXS Inc., Madison, Wis, USA.

[29] EVA V8.0, Graphics Program for 2-Dimensional Data Evaluation and Presentation, BRUKER AXS Inc., Madison, Wis, USA.

[30] F. Galbrecht, T. W. Bünnagel, U. Scherf, and T. Farrell, "Microwave-assisted preparation of semiconducting polymers," Macromolecular Rapid Communications, vol. 28, no. 4, pp. 387-394, 2007.

[31] B. S. Nehls, U. Asawapirom, S. Füldner, E. Preis, T. Farrell, and U. Scherf, "Semiconducting polymers via microwaveassisted Suzuki and Stille cross-coupling reactions," Advanced Functional Materials, vol. 14, no. 4, pp. 352-356, 2004.

[32] K. R. Carter, "Nickel(0)-mediated coupling polymerizations via microwave-assisted chemistry," Macromolecules, vol. 35, no. 18, pp. 6757-6759, 2002.

[33] J. Peet, N. S. Cho, S. K. Lee, and G. C. Bazan, "Transition from solution to the solid state in polymer solar cells cast from mixed solvents," Macromolecules, vol. 41, no. 22, pp. 8655 8659, 2008.

[34] R. F. Cossiell, L. Akcelrud, and D. Z. Atvars, "Solvent and
Molecular Weight Effects on Fluorescence Emission of MEHPPV," Journal of Brazilian Chemical Society, vol. 16, p. 74, 2005.

[35] R. J. Kline, M. D. McGehee, E. N. Kadnikova, J. Liu, J. M. J. Fréchet, and M. F. Toney, "Dependence of regioregular poly(3hexylthiophene) film morphology and field-effect mobility on molecular weight," Macromolecules, vol. 38, no. 8, pp. 33123319, 2005.

[36] T. Yamamoto, Q. Fang, and T. Morikita, "New soluble poly(aryleneethynylene)s consisting of electron-accepting benzothiadiazole units and electron-donating dialkoxybenzene units. Synthesis, molecular assembly, orientation on substrates, and electrochemical and optical properties," Macromolecules, vol. 36, no. 12, pp. 4262-4267, 2003.

[37] T. Yamamoto, D. Komarudin, M. Arai et al., "Extensive studies on $\pi$-stacking of poly(3-alkylthiophene-2,5-diyl)s and poly(4alkylthiazole-2,5-diyl)s by optical spectroscopy, NMR analysis, light scattering analysis, and X-ray crystallography," Journal of the American Chemical Society, vol. 120, no. 9, pp. 2047-2058, 1998.

[38] J. Watanabe, B. R. Harkness, M. Sone, and H. Ichimura, "Rigid-rod polyesters with flexible side chains. 4. Thermotropic behavior and phase structures in polyesters based on 1,4dialkyl esters of pyromellitic acid and 4,4' -biphenol," Macromolecules, vol. 27, no. 2, pp. 507-512, 1994. 

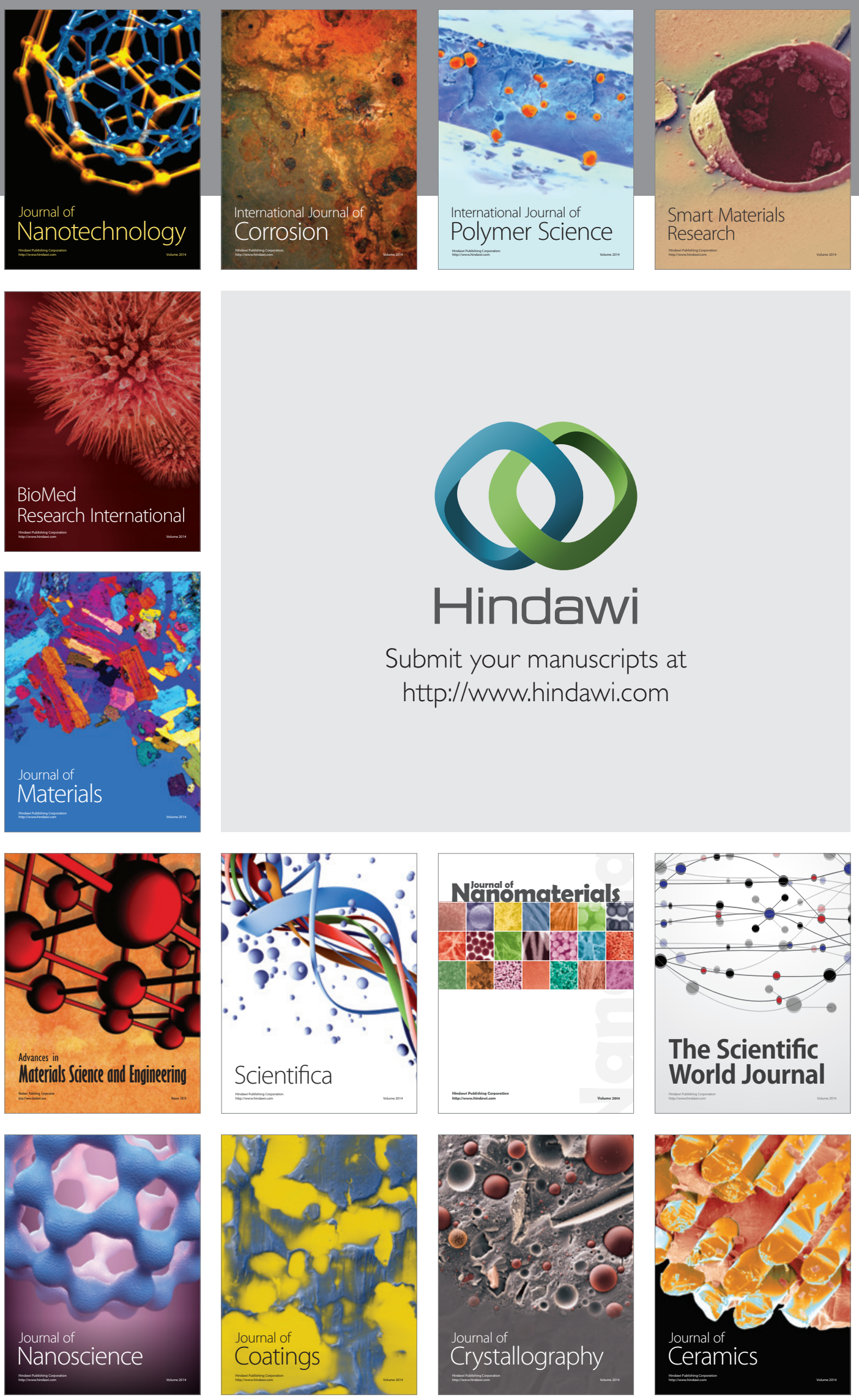

The Scientific World Journal

Submit your manuscripts at

http://www.hindawi.com

\section{World Journal}

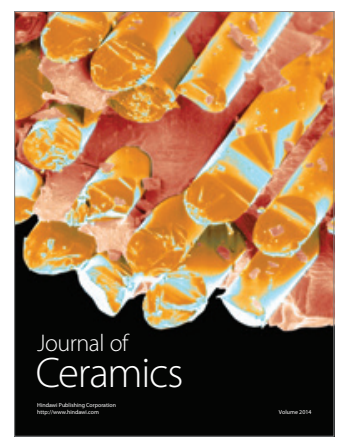

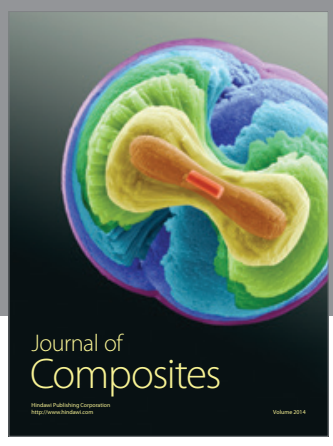
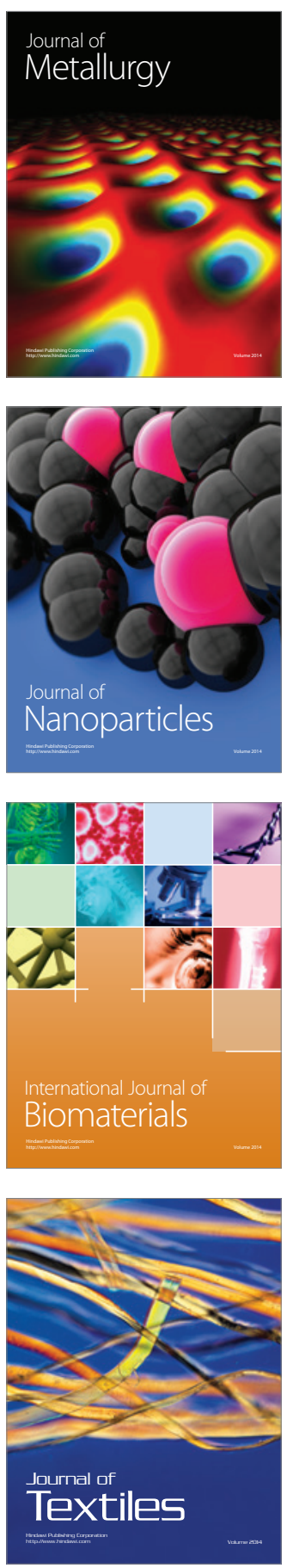